\title{
O-322 グラム陽性菌菌体成分による透析液污染とその生物学的活性
}

大做㲿立大学11、大阪工業大学21

L: I I 健司、武本佳㖽、山上征二、岸本武利 11 、丹羽 允 ${ }^{21}$

(目的) 透析洨はこれまでグうム陰性菌の外膜成分のlipopolysaccharide、いわゆるエンドトキシン(ET) 污染について研究されてきた。しかしET以外のパイロジェンによる污染も危惧される。Silkworm Larvae Plasma(SLP) 侙桨はグラム隣性菌、陰性菌共通の菌体成分であるpeptidoglycan (PG) と真菌の 满成成分の $\beta$ - glucan(BG)により活性化を受ける。したがって、従来までのLAL法、BGの测定法と組み 合わせることで、グラム陽性菌污染の状熊が定量的に測定可能になる。そこで、これらの方法を用いて透 析液污染を検討した。さらに、PG刺激に対するヒト末梢血単核球(PBMC)の各種サイトカイン産生に及ぼ す影暃をin vitroで㭘討した。(方法) 1 . 透析液は 9 の透析施設より透析供給システムの4 カ所a)RO water b)多人数用透析液供給装置 C)多人数用透析機末端 d)個人用透析機末端の計 54 ヶ所より無菌的に 採取し、LAL法、G法、SLP法を用いて各サンプルの污染度を調へた。2.健常人、血液透析患者各10名 の末梢血単核球を採取し、LPS，PG(MDP)，LPS+PGで刺激させ、24時間培養後IL-1Ra，IL-1 $\beta ， T N F-\alpha$ をELISA法にて测定した。(結果) 1.PG( おいては平均で c) $4.05(\mathrm{ng} / \mathrm{ml})$ d) $3.03(\mathrm{ng} / \mathrm{ml})$ と污染が認めれ、PGの単独污染やET,BGとの混合涯 染も瑟められた。2.PBMCのIL-1 Ra,IL-1 $\beta$,TNF- $\alpha$ の産生は、PGの濃度依存性に增大した。また、PG 及びETが相乘的に作用して、それぞれ単独刺激の場合よりもサイトカイン産生が5-10倍有意に增幅され た。(結語) 従来からET污染だけとされていた透析液にはPGが含まれていた可能性があり、ETとPGは相 乘作用を示しサイトカイン産生を誘首する。したがって、透析液污染はETだけでなく、PGに対しても十 分に注意する必要がある。

O-323 高へマトクリット症例におけろブラッドアクセス開存率

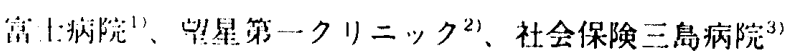

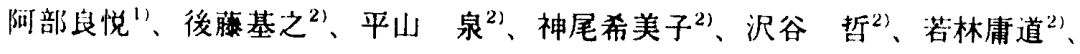

竹内弘幸 ${ }^{3 \prime}$

【目的】正常域にあるへマトクリット（Ht）值の、透析患者に対する、特に内シャントに対する影響を調 べた。【対象と方法】 $\mathrm{Ht}$ 值35\%以上の期間が半年以上続いた14例を対象とした。年俆の平均は $56 \pm 11.2$

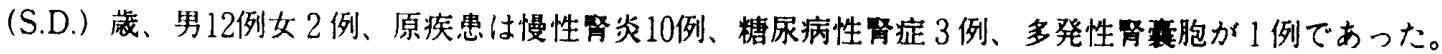
エリスロポエチン（Epo）製戍投与を契機としてHt值が上界したものは11例であった。個々の内シャン トの開存期間から、Kaplan Meire法によって開存曲線を描出した。QOL調查として患者アンケートを 行なった。その中で、経騃した種々の Ht 值レベルにおいて容易に行ない得なかった日常動作を選択させ た。血小板の准集能に影響を及はす薬郕の使用状況、血圧や透析効率の変動についても検討を加之た。

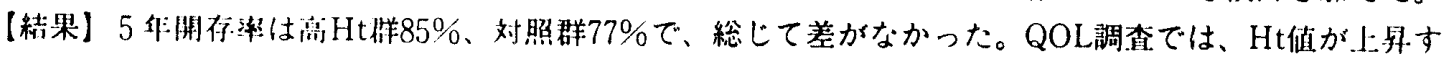
るほど連動負荷の大きい日常動作が容易になった。30\%台と40\%以上の間でも明らかな改善がみられた。 血小板凝集能に影響を及はす薬郕の使用状況では、高Ht群における塩酸チクロピジンの使用頻度が比較 的高かった。その使用目的の大半は内シャントの閉塞予防であった。透析終了時での回路内残血はいず

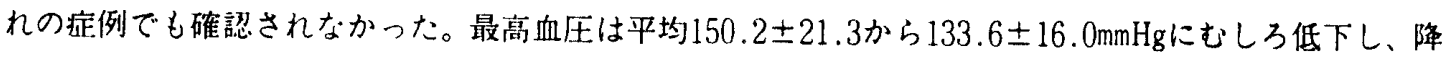
压剤の服用は 4 例から 3 例に減つた。透析時間、血流速度およびクリアランスの各平均值は微增してい

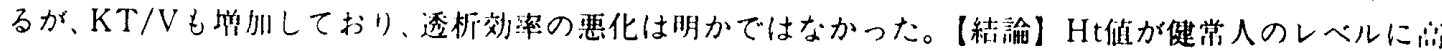
くなっても、内シャントの閏存针や、残血、血圧、透析効事の点で䦓題を生じなかった。QOLの点では

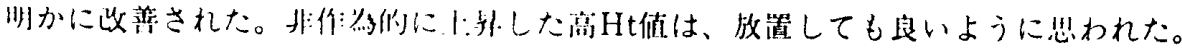

